\title{
Pralina Bhumi: Imajinasi Pandemi Covid-19 Kedalam Karya Fotografi Ekspresi
}

\author{
I Made Bayu Pramana
}

Institut Seni Indonesia Denpasar

bayupramana@isi-dps.ac.id

Wabah Covid-19 yang sedang menyerang kesehatan manusia di seluruh dunia, tidak terkecuali Indonesia. Untuk mengurangi resiko penularan, pemerintah menyarankan agar masyarakat berdiam diri di rumah. Hal tersebut juga menyulitkan untuk berkarya seni khususnya fotografi yang relatif lebih sering dilakukan di luar ruangan. Untuk itu, pencipta mencoba untuk menggali ide dasar melakukan kegiatan penciptaan karya fotografi ekspresi terkait tema penyebaran Covid-19 dengan tetap memperhatikan prinsip keamanan dari transmisi penularan virus. Salah satunya adalah dengan memotret benda benda sederhana yang ada di sekitar pencipta yang diimajinasikan serta dikreasikan mentrasformasikan imaji kerusakan yang ditimbulkan oleh pandemi Covid-19. Berbagai rekaman realitas berupa penguraian benda yang perlahan menuju pengerusakan secara fisik yang lebih dominan berupa tekstur-tekstur kasar tidak beraturan tersebut akan disajikan dalam media fotografi berwarna agar detail, dimensi, pencahayaan, serta karakter dari kehancuran fisik dapat tampil optimal dalam saturasi dan tonasi tinggi. Pemilihan genre foto ekspresi digunakan memvisualisasikan karya fotografi yang merefleksikan kenyataan ke dalam sebuah karya yang bentuk dan isinya memiliki daya untuk membangkitkan pengalaman tertentu didalam rohani si penerima. Selain itu, foto ekspresi juga digunakan sebagai salah satu cara dalam mengkomunikasikan sebuah pesan dari seniman kepada para penerima pesan dengan memerhatikan aspek keindahan.

Kata kunci : imajinasi, pandemi, fotografi ekspresi, pralina

Proses review: 1 - 15 September 2021, Dinyatakan lolos 17 September 2021 


\section{PENDAHULUAN}

Wabah Covid-19 yang sedang menyerang kesehatan manusia di seluruh dunia, tidak terkecuali Indonesia. Untuk mengurangi resiko penularan, pemerintah menyarankan agar masyarakat berdiam diri di rumah. Hal tersebut juga menyulitkan untuk berkarya seni khususnya fotografi yang relatif lebih sering dilakukan di luar ruangan. Pencipta mencoba untuk menggali ide dasar melakukan kegiatan penciptaan karya fotografi ekspresi terkait tema penyebaran Covid-19 dengan tetap memperhatikan prinsip keamanan dari transmisi penularan virus. Salah satunya adalah dengan memotret obyek sederhana yang ada di sekitar pencipta yang diimajinasikan serta dikreasikan mentrasformasikan imaji microscopic detail visual virus Covid-19.

Berbagai peristiwa dan kejadian di sekitar kita pada dasarnya dapat menjadi sumber inspirasi bagi penciptaan karya seni (Wirakusuma, 2017:100). Banyak hal-hal yang dianggap sebagian besar orang kebanyakan sebagai sesuatu yang tidak berguna sama sekali, namun bagi orang-orang yang memiliki daya kreatifitas pandang, benda-benda tak berguna yang mengalami kehancuran seperti itu dapat saja diolah atau didaur-ulang kembali menjadi sesuatu yang baru, bernilai dan bermanfaat. Sementara bagi seniman fotografi, hal seperti itu dapat dijadikan inspirasi dalam penciptaan karya seni yang memiliki nilai orisinalitas tinggi.

Dari pertimbangan tersebut, pencipta mencoba untuk menggali ide dasar melakukan kegiatan penciptaan karya fotografi ekspresi terkait tema penyebaran Covid-19 dengan tetap memperhatikan prinsip keamanan dari transmisi penularan virus. Salah satunya adalah dengan memotret benda benda sederhana yang ada di sekitar pencipta yang diimajinasikan serta dikreasikan mentrasformasikan imaji kerusakan yang ditimbulkan oleh pandemi Covid-19.

Berdasarkan uraian diatas, ide untuk mengelaborasi Pralina Bhumi: Imajinasi Pandemi Covid 19 dalam karya fotografi ekspresi, muncul dari kekaguman atas kebesaran Yang Kuasa atas berbagai fenomena peleburan fisik yang diakibatkan oleh siklus perubahan baik alamiah maupun buatan manusia. Berbagai rekaman realitas berupa penguraian benda yang perlahan menuju pengerusakan secara fisik yang lebih dominan berupa tekstur-tekstur kasar tidak beraturan tersebut akan disajikan dalam media fotografi berwarna agar detail, dimensi, pencahayaan, serta karakter dari kehancuran fisik dapat tampil optimal dalam saturasi dan tonasi tinggi.

Untuk menunjang tampak rekam yang lebih tajam serta memunculkan beragam struktur dan detaildetail unik dari karakter kehancuran yang seringkali sulit dilihat dengan mata telanjang, digunakan lensa macro yang dapat mengamati secara detail sesuatu yang amat kecil. Selain itu, penggunaan lensa macro juga dimaksudkan untuk memperjelas dan memperbesar berbagai struktur kerusakan beserta detailnya yang tampak biasa saja oleh mata awam, namun akan menjadi sesuatu yang mengejutkan saat diperbesar secara optical. Terkait dengan imajinasi Covid-19, seluruh foto yang dihasilkan mengacu kepada imaji visual yang muncul dari inspirasi microscopic detail virus corona dalam foto.

\section{KAJIAN SUMBER PENCIPTAAN}

\section{Pengertian Pralina}

Pralina pada dasarnya adalah sebuah proses alam yang menurut keyakinan Agama Hindu berkaitan dengan eksistensi Tuhan dalam menjalankan fungsinya. Adapun tugas tugas tersebut termanifestasikan dalam perwujudanperwujudan sifat keTuhanan yang tertuang dalam konsep Tri Murti, yang menurut penjabaran kamus Agama Hindu berarti tiga manifestasi Tuhan yang diwujudkan sebagai Brahma, Wisnu, Siwa.

Ketiga manifestasi tersebut memiliki tugas dalam menjalankan fungsinya masing-masing dalam rangka menyeimbangkan dunia dengan sebutan Tri Kona dengan jabaran Uttpati, Stithi, dan Pralina. Batara Brahma yang dilambangkan dengan sifat api menjalankan tugasnya sebagai pencipta segala isi dunia, Wisnu dilambangkan dengan sifat air yang menyejukan betugas untuk memelihara dan menjaga eksistensi seisi jagat raya dan Siwa yang dimanifestasikan dalam wujud Rudra (Siwa) bertugas melebur dunia serta mengembalikan semua unsur ciptaan ke asalnya pada saat sudah tidak lagi dibutuhkan keberadaannya di dunia.

\section{Pengertian Fotografi Ekspresi}

Seni fotografi merupakan bagian sektor industri kreatif. Pemerintah telah menetapkan 14 subsektor lingkup industri kreatif, meliputi arsitektur, periklanan, barang seni (lukisan, patung), kerajinan, 
desain, mode atau fesyen, musik, permainan interaktif, seni pertunju-kan, penerbitan dan percetakan, layanan komputer dan piranti lunak, radio dan telelisi, riset dan pengembangan, serta film-video dan fotografi (Saryana, dkk., 2018: 155). Keberadaan foto ekspresi merupakan sebuah karya fotoyang mengarah kepada perkembangan seni murni / lukis, yang didalam sisi visualnya mengandung kekayaan akan konsep dan tema serta mengandung nilai-nilai tertentu di dalamnya. Biasanya dalam proses pengerjaan foto ekspresi, pemotret cenderung melakukan berbagai eksperimen tertentu sebelum tercipta foto yang sebenarnya (Zahar, $2003: 28$ ).

Dari pengertian diatas, dapat dikatakan bahwa fotografi ekspresi merupakan kegiatan transfer pesan secara visual yang berdasarkan pengalaman sang fotografer yang merangkap sebagai komunikator kepada penyampaian pesan secara visual dari pengalaman yang dimiliki fotografer kepada komunikan dengan tujuan untuk mempengaruhi jalan pikirannya. Salah satu aspek kekuatan sebuah karya fotografi adalah aspek estetika atau pengalaman estetik dari sebuah foto (Purnomo, 2019:320

\section{Pengertian Pandemi Covid-19}

Covid-19 (coronavirus disease 2019) adalah penyakit yang disebabkan oleh jenis coronavirus baru yaitu Sars-CoV-2, yang dilaporkan pertama kali di Wuhan Tiongkok pada tanggal 31 Desember 2019. Covid-19 ini dapat menimbulkan gejala gangguan pernafasan akut seperti demam diatas $38^{\circ} \mathrm{C}$, batuk dan sesak nafas bagi manusia. Selain itu dapat disertai dengan lemas, nyeri otot, dan diare. Pada penderita Covid-19 yang berat, dapat menimbulkan pneumonia, sindroma pernafasan akut, gagal ginjal bahkan sampai kematian.

Covid-19 dapat menular dari manusia ke manusia melalui kontak erat dan droplet(percikan cairan pada saat bersin dan batuk), tidak melalui udara. Bentuk Covid-19 jika dilihat melalui mikroskop elektron (cairan saluran nafas/ swab tenggorokan) dan digambarkan kembali bentuk Covid-19 seperti virus yang memiliki mahkota.

\section{Acuan Karya}

Pada proses menciptakan sebuah karya seni, setiap seniman tentunya memiliki pengalaman estetik dan pengaruh secara langsung maupun tidak langsung terhadap karya seniman lainnya yang memiliki ciri khas kekaryaan serupa.
Adapun beberapa foto yang layak dijadikan sumber acuan berkarya terkait dengan Pralina yaitu :

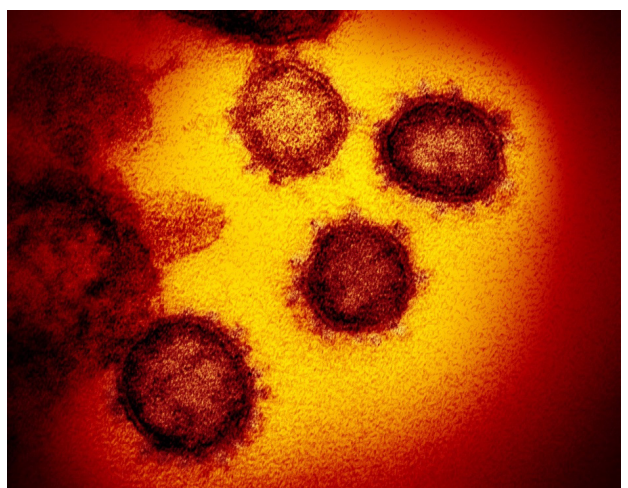

Gambar 1. Foto detail virus covid-19 dengan tangkapan transmisi mikroskop electron

(Sumber foto : NIAID-RML HTTPS://WWW.NEPM.ORG/ POST/IMAGES-WHAT-NEW-CORONAVIRUS-LOOKS-UNDER-MICROSCOPE\#STREAM/o)

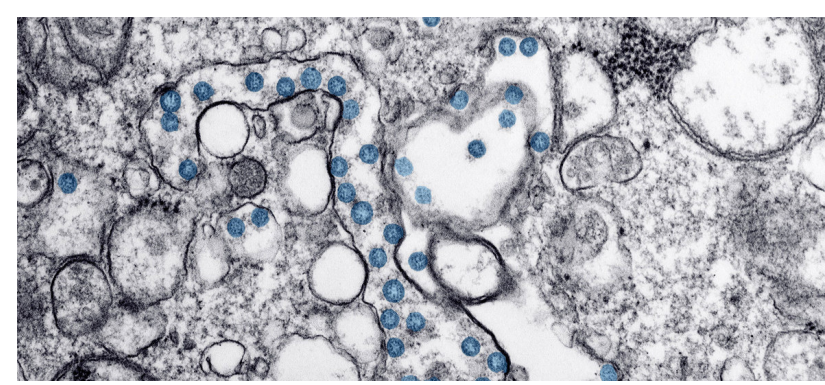

Gambar 2. Gambar mikroskopik detail infeksi yang ditimbulkan oleh virus covid-19

( Sumber foto : CDC/Hannah A Bullock/Azaibi Tami https:// news.un.org/en/story/2020/05/1063072)

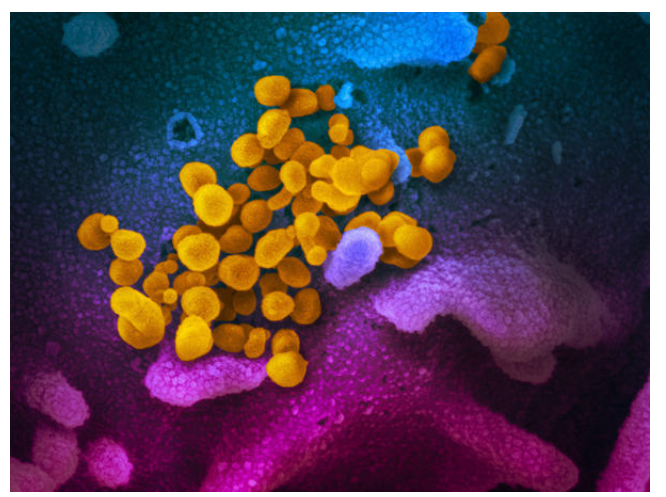

Gambar 3. Gambar detail covid-19 virus dalam warna kuning yang berkembang dari sel berwarna biru dan pink yang direkam dengan mikroskop elektron. (Sumber foto : NIAID-RML

https://www.nepm.org/post/images-what-new-coronavirus-looks-under-microscope\#stream/o) 


\section{TEORI DAN METODE}

Dalam proses memvisualisasikan karya fotografi yang mengangkat Pralina; Imajinasi Pandemi Covid-19 Kedalam Karya Fotografi Ekspresi, diperlukan beberapa teori. Untuk mewujudkan karya fotografi tentang pralina, digunakan beberapa teori, antara lain:

\section{Teori Pendekatan}

Sebelum melakukan pemotretan, pendekatan merupakan satu hal yang mutlak harus dilakukan oleh pemotret, disamping untuk mengenal objek lebih detail, pendekatan juga bertujuan untuk memberikan nilai pribadi pada karya fotografinya.

Pendekatan menurut Soedjono, dikutip dari Zakia (2002:118). dapat dilakukan dengan tiga cara yang berbeda yaitu :

Projection merupakan upaya si fotografer dalam memproyeksikan apa yang dirasakan oleh dirinya terhadap objek fotonya dengan melibatkan perasaannya pada saat memotret.

Introjection merupakan upaya si fotografer untuk meluangkan waktu yang lebih banyak dalam mempelajari objek fotonya, sehingga dapat menghasilkan karya foto dari sebuah objek yang memang sesuai dengan kondisi, karakteristik dan sifat dari objek tersebut.

Confluence merupakan upaya pendekatan dari si fotografer untuk menyatukan dirinya dengan objek yang dipotretnya, sehingga dapat dihasilkan sebuah karya yang dapat dikatakan mewakili si pemotret. (Soedjono, 2002 : 118).

Jadi untuk menciptakan karya fotografi yang menarik, mempunyai ciri khas pribadi dan dapat mewakili pribadi pemotret, teori pendekatan di atas digunakan dalam proses pemotretan di lapangan.

\section{Teori 5C}

Teori ini dipergunakan untuk mengulas dan menganalisis foto dari berbagai segi teknis yang dimulai dengan huruf $\mathrm{C}$ dalam bahasa Inggris, pertama kali diperkenalkan oleh Joseph V. Mascelli , yakni :

Camera Angle (Sudut kamera) : adalah penentuan sudut pandang gambar, dalam artian dari sisi mana objek dapat terlihat paling baik, sehingga dapat dimunculkan posisi gambar yang sempurna.

Continuity (Pengisian ruang) : Untuk menghindari ruang yang kosong secara berlebihan diperlukan beberapa elemen pengisi ruang kosong di sekitar objek utama, hal ini diperlukan untuk memberikan keseimbangan (balancing) dalam gambar.

Composition (Komposisi) : dalam memotret, komposisi merupakan salah satu hal yang sangat penting untuk menampilkan bidang foto yang baik di pandang oleh mata. Komposisi meliputi penampilan ruang dan bidang gambar, serta membuang bidang yang tidak cocok dimasukan ke dalam rekaman gambar.

Close-up(Pengambilangambar): untukmenampilkan detail dari gambar, diperlukan pengambilan secara close-up, sehingga memunculkan bagian yang paling utama dari objek dan sekaligus menjadi pusat perhatian (focus of interest) dari sebuah foto.

Camera Editing (Pengolahan pasca pemotretan) : setelah tombol rana kamera disentuh maka telah terekam sebuah gambar pada kamera, untuk memaksimalkan penampilan sebuah karya foto diperlukan sebuah pengolahan setelah pemotretan.

\section{Teori Studium dan Punctum}

Menurut Roland Barthes dalam Ajidarma, sebuah imaji fotografi terdapat Studium dan Punctum. Studium merupakan kesan keseluruhan secara umum yang akan mendorong seorang pemandang foto memutuskan sebuah foto bersifat politis atau historis, indah atau tak indah, yang mengakibatkan reaksi suka tidak suka.

Sebaliknya Punctum merupakan fakta yang terinci dalam sebuah foto yang menarik dan menuntut perhatian pemandang, ketika memandangnya secara kritis, tanpa mempedulikan Studium. Dalam Punctum itu nantinya dapat dipahami mengapa seseorang terus menerus dapat memandang atau mengingat sebuah foto (Ajidarma, 2002 : 28).

Dari teori di atas, secara umum dapat diarahkan pembentukan karya yang nantinya dapat memberi kesan mendalam pada penikmat foto. 


\section{KONSEP PERWUJUDAN KARYA}

Dalam proses mewujudkan "Pralina" ke dalam karya fotografi, diperlukan sebuah konsep yang matang dan jelas batasannya dalam rangka membentuk karya sesuai dengan landasan berkarya. Dalam berbagai pengamatan terhadap objek yang akan ditrasformasikan menjadi karya foto bertemakan "Pralina", berbagai benda-benda yang mengalami proses kehancuran fisik dipilih sebagai alternatif. Berbagai benda tersebut tentu saja yang memiliki berbagai batasan kelayakan untuk dapat direkam menjadi karya fotografi bernilai estetik tinggi. Secara terencana dalam proses pengamatan dipilih proses kehancuran alamiah yang membentuk sebuah profil tertentu dalam kandungan visualnya, baik pada bagian yang mengalami kehancuran, maupun bagian yang tersisa dari keseluruhan objek yang mengalami kehancuran.

Penemuan objek yang memiliki bentuk profil tersebut, tentunya melalui proses imajinasi pandang terhadap objek. pemilihan secara lebih detail dikhususkan lagi dalam bentuk kerusakan, namun memilik bentuk, bidang atau dimensi yang dapat mengasosiasikan makna tertentu bagi pemotret dan diterjemahkan secara fotografis sehingga dapat dinikmati juga oleh khalayak. Pengambilan gambar tentunya juga dipilih dari sisi tertentu objek yang dianggap paling menarik secara close up dengan menggunakan bantuan lensa macro.

Dalam rangka mempertahankan keaslian objek secara fotografis, pengolahan secara digital dilakukan hanya sebatas contrast, level dan cropping. Setelah proses pengolahan di piranti lunak komputer, pengkemasan karya dilakukan dengan mencetak foto pada media photo canvas yang lebih memunculkan tekstur yang terkandung pada foto, selain mempertajam warna serta mempertahankan kualitas gambar dalam jangka waktu lama.

Pada saat pembingkaian, akan ada beberapa kesatuan gambar yang terdiri lebih dari satu foto yang dipasang dalam spanram berbeda ketebalan, sehingga diharapkan dapat memunculkan kesan tiga dimensi dan kedalaman pada karya yang nantinya disajikan.

\section{PROSES PENCIPTAAN}

Benda-benda yang mengalami proses pralina dalam pengamatan saya berubah menjadi berbagai imajinasi estetik yang memiliki kandungan keindahan di dalamnya. Akumulasi dari kekaguman terhadap fenomena kehancuran fisik dengan kecintaan pada fotografi mendorong kreativitas Pencipta untuk mentransformasikannya ke dalam karya fotografi. Seperti yang diungkapkan oleh Seno Gumira Ajidarma bahwa teknologi fotografi memang dilahirkan untuk memburu objektivitas, karena kemampuannya untuk menggambarkan kembali realitas visual dengan tingkat presisi tinggi (Ajidarma, 2002:1).

Tidak kalah pentingnya juga dalam foto-foto yang akan disajikan diperlukan berbagai pengamatan ulang dari berbagai angle untuk menginterpretasi setiap makna yang terkandung dalam bidang visual sebuah karya fotografi. Menilik pendapat Barrett dalam Soedjono (2006:38) bahwa semua upaya interpretasi merupakan kegiatan "membaca" karya fotografi yang diasosiasikan sebagai teks. Suatu teks yang memiliki prinsip mendasar bahwa karya fotografi memiliki makna yang lebih dari sekedar yang ternampakkan.

Dari pendapat di atas dapat diarahkan seluruh karya yang dihasilkan nantinya akan dapat memiliki makna tertentu sesuai dengan pesan yang ingin disampaikan kepada khalayak, yang kemudian juga diharapkan dapat memahami, dan memaknai berbagai elemen visual yang terkandung dalam karya foto. Dengan kata lain foto yang disajikan mengandung makna dan lebih dari itu, penikmat karya dapat menangkap siratan makna dari foto yang disajikan.

Adapun tahapan-tahapan yang dilakukan dalam rangka proses penciptaan karya yang kreatif, inovatif serta kaya makna antara lain :

\section{Tahap Eksplorasi dan Observasi}

Eksplorasi dan observasi dilakukan dengan mengamati secara mendetail berbagai benda-benda yang mengalami proses kerusakan secara fisik, baik berupa material logam, kayu, daun, tanah, serta berbagai jenis benda lainnya. 
Pekerjaan memotret benda-benda yang direncanakan di atas seolah sangatlah sederhana, karena banyak yang mengira proses pemotretannya hanyalah mengarahkan kamera ke subjek, lalu menekan shutter release dan jadilah foto yang diinginkan. Padahal proses tersebut hanya sebagian kecil dari rangkaian penciptaan karya fotografi.

Sebelum sebuah kegiatan yang bernama memotret dimulai, penguasaan teknis yang baik. Hal-hal yang bersifat teknis dalam melakukan sebuah pemotretan tidak dapat dipelajari dengan instan, karena diperlukan waktu yang cukup panjang untuk menguasai kamera dan berbagai fitur fungsinya, dan tentu saja teknis yang telah dikuasai harus terus dicoba dan dipraktekkan dalam rangka menambah jam terbang seorang pemotret meliputi penggunaan kamera, shutter speed, diafragma, ISO, penggunaan lensa dan pengkombinasian pencahayaan yang tepat sangat dibutuhkan. Penguasaan teknis di atas juga harus ditunjang dengan kepekaan memilih komposisi yang tepat dalam mentransformasikan gambar agar didapatkan sudut terbaik dalam karya foto.

\section{Proses dan tahapan pemotretan}

Melanjutkan proses pengamatan yang telah dijelaskan dalam tahapan observasi, sebuah kegiatan mendapatkan dam memilih objek dilakukan secara seksama. Pemilihan secara umum didasarkan pada benda yang mengalami proses kehancuran fisik. Jadi karena menampilkan proses, maka dalam visualisasi karya dipilih objek yang memiliki perbandingan antara bidang utuh dan bidang yang sudah mengalami pelapukan. Tidak hanya itu, pemilihan secara lebih detail dikhususkan lagi dalam bentuk kerusakan, namun memilik bentuk, bidang atau dimensi yang dapat mengasosiasikan makna tertentu bagi pemotret dan diterjemahkan secara fotografis sehingga dapat dinikmati juga oleh khalayak. Pengambilan gambar tentunya juga dipilih dari sisi tertentu objek yang dianggap paling menarik secara close up.

Dalam proses pemotretan, keberadaan cahaya dan arah datangnya cahaya menjadi pertimbangan yang sangat penting dalam mendukung pemotretan. Karena unsur cahaya tersebutlah yang nantinya akan memberikan dimensi pada objek yang akan difoto. Selain itu, unsur-unsur lainnya yang tak kalah penting adalah bagaimana menyusun warna, garis, tekstur dan bidang ke dalam sebuah bidang komposisi yang dilihat dari berbagai sudut pandang /

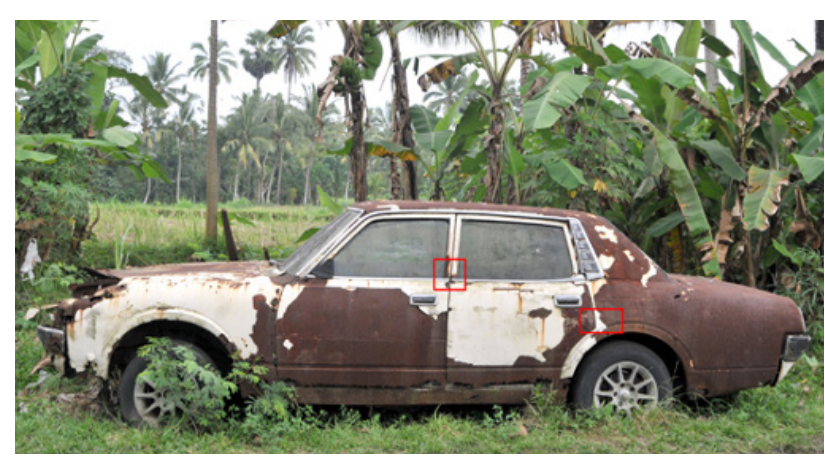

Gambar 4. Pemilihan sisi objek paling menarik dalam proses observasi dan Pemotretan.

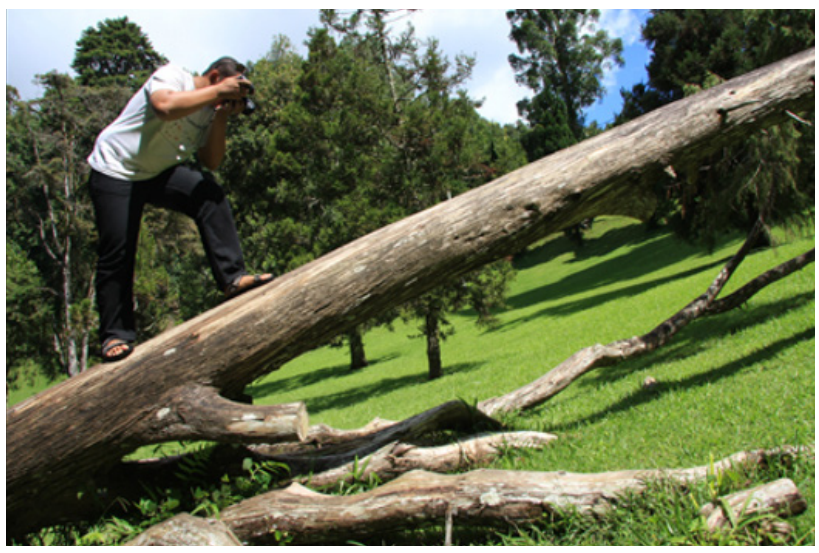

Gambar 5. Salah satu proses pemotretan

angle pemotretan agar dapat diraih hasil pemotretan optimal, sesuai dengan prinsip teori $5 \mathrm{C}$ yang telah dipaparkan di atas.

\section{Eksperimen dan Pengolahan/Penciptaan Karya}

Setelah tahap pemotretan selesai dilakukan, soft copy foto yang tersimpan di memory card kemudian diunduh ke perangkat komputer. Melanjutkan proses pemindahan data tersebut, foto yang telah terkumpul kemudian diseleksi melalui sebuah proses pemilihan dengan program Nikon View $N X ®$, yang meliputi pengontrolan fokus, ketepatan eksposur dan ketajaman gambar. Gambar yang telah melewati tahapan seleksi awal disimpan dalam sebuah folder khusus agar memudahkan pencarian dan penyimpanan gambar. Foto yang telah lolos seleksi kemudian diatur kematangan warna dan saturasinya dalam Nikon Capture NX®, sebuah piranti lunak yang dikhususkan untuk mengolah foto yang dihasilkan oleh kamera Nikon. Adapun dalam software ini pengolahan warna dapat dilakukan dalam pilihan warna yang diinginkan saja sesuai kebutuhan dan area yang diseleksi. 


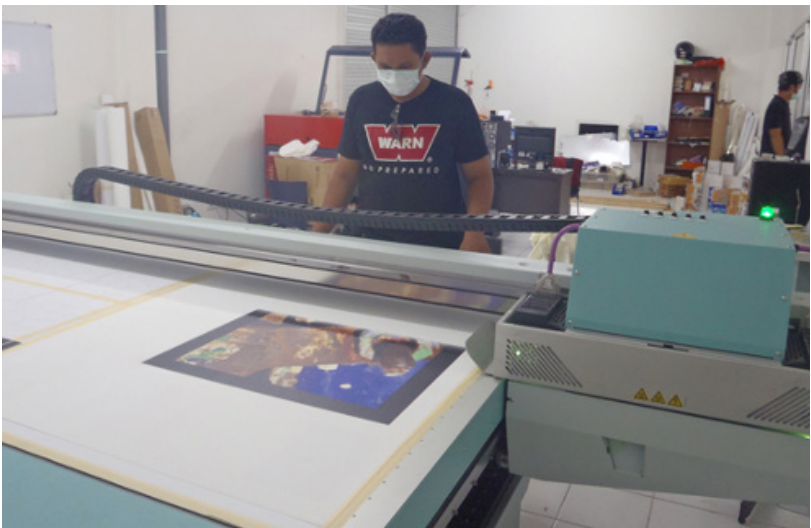

Gambar 6. Pencetakan karya pada media photo canvas dengan Flat Bed printer

Proses selanjutnya dilakukan dengan pengolahan gambar melalui piranti lunak computer yaitu Adobe Photoshop. untuk mengoptimalisasi kualitas gambar dengan fitur-fitur seperti : level, contrast, selective color, penambahan saturasi dan penajaman gambar dengan sharpen jika dibutuhkan. Dalam beberapa bidang gambar yang tidak diperlukan, dilakukan juga pemotongan gambar dengan fitur cropping. Selain itu, penentuan ukuran cetak (resize) juga langsung dilakukan di komputer sebelum proses pencetakan dilakukan. Pengolahan yang berlebihan di komputer memang sedikit dihindari karena proses untuk mendapatkan gambar yang prima sudah dimulai sebelumnya pada saat proses pengamatan, pemilihan objek, pemilihan detail yang akan di foto, dilanjutkan pada pemilihan angle serta pemanfaatan pencahayaan yang baik untuk mendapatkan eksposur yang tepat.

\section{Penampilan Akhir Karya}

Setelah karya diolah lewat piranti lunak computer, pengkemasan karya akan sangat mempengaruhi tampilan keseluruhan karya, untuk itu penampilan akhir harus dilakukan semaksimal mungkin dengan beberapa cara. Salah satunya adalah dengan mencetak foto pada media photo canvas yang akan lebih memunculkan tekstur yang terkandung pada foto, selain mempertajam warna serta mempertahankan kualitas gambar dalam jangka waktu lama. Proses pencetakan dilakukan dengan mesin cetak Flat Bed.

Seluruh foto yang telah tercetak pada media photo canvas kemudian dipasang dengan cara dibentangkan dengan spanram sesuai dengan kebutuhannya. Pemilihan spanram dilakukan sesuai dengan foto yang ditampilkan dan kebutuhan ketebalan yang diinginkan. Pada saat pemasangan spanram tersebut, akan ada beberapa kesatuan gambar yang terdiri lebih dari satu foto yang dipasang dalam spanram berbeda ketebalan seperti $1,5 \mathrm{~cm}, 3 \mathrm{~cm}, 4 \mathrm{~cm}$ dan 5 $\mathrm{cm}$. Sehingga diharapkan dapat memunculkan kesan tiga dimensi dan kedalaman pada penampilan akhir karya yang nantinya disajikan dalam pameran.

Karya yang telah tercetak, dalam pameran akan dipasang tidak sesuai dengan apa yang terlihat dalam kenyataan dalam arti saat pemasangannya foto dipasang dengan melakukan rotasi sebelumnya. Bisa jadi diputar 90 derajat hingga 180 derajat dalam penampilannya. Hal tersebut dilakukan untuk melakukan sebuah rekayasa posisi pandang atau pemasangan karya, selain juga dapat membuka peluang dan potensi pengalihan makna dari apa sebelumnya yang tersaji di alam berbanding terbalik dengan apa yang tersaji dalam pameran karya foto. Jadi apa yang sebelumya terlihat di view finder kamera dapat tersaji berbalik dengan apa yang disajikan dalam tahapan akhir karya di pameran.

Di sisi lain, cara pemasangan demikian juga sebagai salah satu bentuk pemaksaan visual kepada penikmat karya seni untuk melihat sesuai dengan gaya cara pandang seorang pemotret. Mengingat seorang seniman melihat dengan gayanya sendiri dan harus diikuti oleh siapapun yang ingin menikmati karya seni yang disajikannya.

\section{Tahapan Analisis dan Sintesis Karya}

Seluruh karya yang sudah dihasilkan kemudian perlu di analisis dalam sebuah diskursus yang bersifat membangun kekaryaan secara positif, dalam rangka melakukan apresiasi, interpretasi serta tak kalah pentingnya eveluasi tentang kualitas karya. Secara lengkap analisis tentang ulasan karya akan ditampilkan dalam bab IV nanti, namun lebih awal uraian tentang proses analisis akan dijelaskan sebelumnya. Menurut Edmund Burke Feldman ada tahapan-tahapan dalam menganalisis karya fotografi, yang tersirat dalam Soedjono (2006:86), antara lain : Description, merupakan proses mengumpulkan dan menjelaskan hal-hal yang berkaitan dengan karya seninya.

Formal Analysis, merupakan proses untuk mengurai dan mencari hubungan antara satu elemen dengan elemen lainnya baik dari segi struktur bentuk, warna, dan unsur pembentuk lainnya dalam penampilan fisik karya seni. 
Interpretation, merupakan proses pencarian dan pemahaman makna keseluruhan yang didapatkan dari hasil analisis kedua proses sebelumnya terhadap keberadaan / kehadiran sebuah karya seni.

Judgment, merupakan sebuah upaya untuk menilai dan memberikan klasifikasi tertentu terhadap karya seni dengan membandingkannya dengan karya sejenis. Meskipun penilaian ini kadang bersifat subjektif, namun tetap diupayakan agar tetap seobjektif mungkin.

Tahapan Judgment dalam ulasan karya nanti tidak akan dilakukan karena dalam proses penciptaan karya seni tugas akhir tidak diharapkan untuk membandingkan karya seni secara langsung, namun lebih banyak pada proses kreatif dan penyampaian pesan yang terkandung di dalam karya foto.

\section{KARYA FOTO \& ULASAN KARYA}

Seluruh karya yang sudah dihasilkan dan dikemas secara kreatif tentunya perlu dianalisis dalam rangka membangun kualitas kekaryaan secara positif, selain melakukan apresiasi, interpretasi serta tak kalah pentingnya evaluasi tentang kualitas karya berkaitan dalam kaedah akademis. Secara umum dalam proses mengulas karya foto agar bersifat objektif, akan dilakukan sebuah proses pengulasan yang menurut Edmund Burke Feldman memenuhi poin-poin antara lain: Description, Formal Analysis, Interpretation, yang memungkinkan seluruh unsur teknis dan non teknis dalam foto dapat diuraikan.

Serta tak kalah pentingnya berbagai pemaknaan yang dapat diapresiasi dan diinterpretasi dari sebuah foto dapat dimaknai dengan baik, sebagai sebuah komunikasi dari seniman fotografi kepada penikmat karya. Dari situ akan dapat dinilai seluruh proses dalam penciptaan karya ini dapat terwujud atau tidak. Selain agar penikmat dapat memahami dan mengapresiasi maksud yang disampaikan dalam sebuah karya.

Karya Foto yang berjudul "Taru Pralina" ini menampilkan tiga panel foto kulit kayu yang mengalami proses pelapukan fisik secara alamiah. Proses pelapukan tersebut memberikan berbagai dimensi baru pada permukaan kayu. Terlihat jelas munculnya beberapa guratan garis dari berbagai arah, tekstur berupa titik-titik serupa teknik pointilis dalam seni lukis. Titik-titik tersebut juga seolah memberi kesan tiga dimensi pada karya foto. Dari
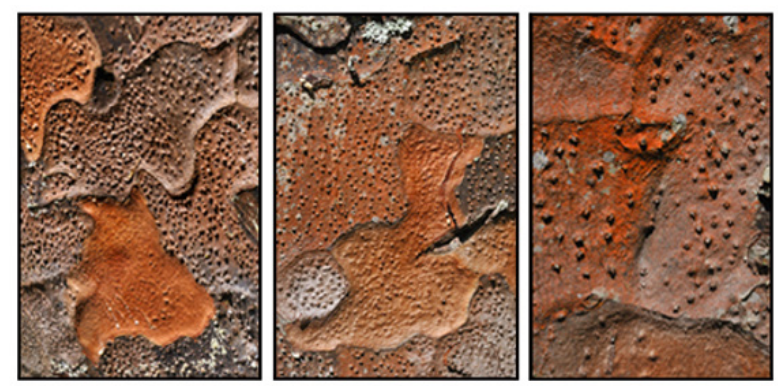

Gambar 7. Karya 1. Taru Pralina

Foto Digital print pada Photo Canvas, $80 \mathrm{~cm}$ x $100 \mathrm{~cm}$

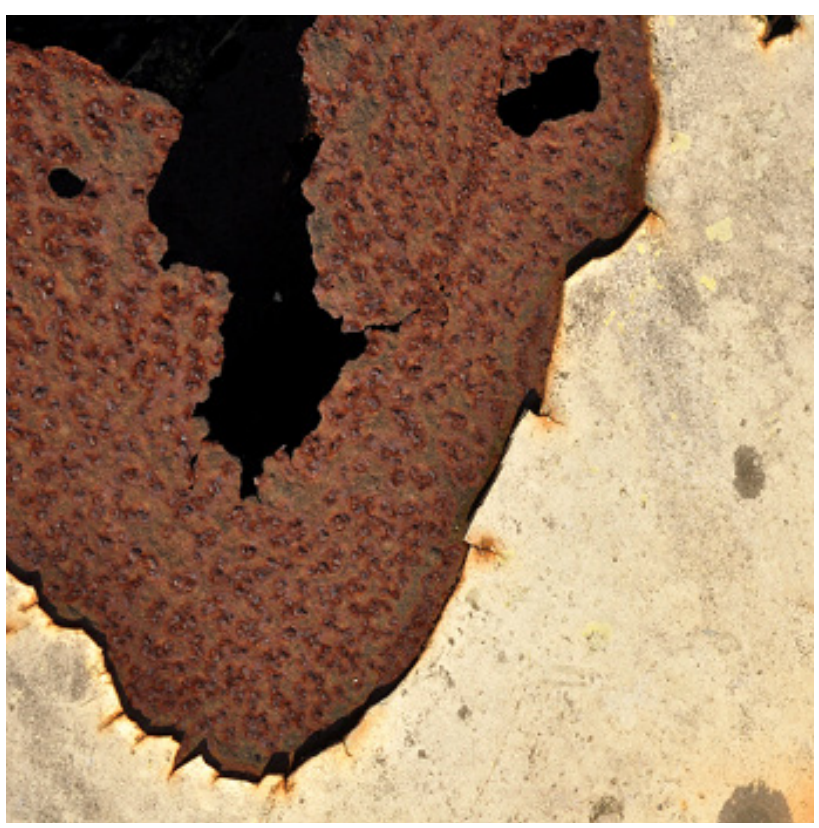

Gambar 8. Karya 2. Antara Hidup dan Mati

Foto Digital print pada photo canvas, $100 \mathrm{~cm} \times 100 \mathrm{~cm}$

keseluruhan gambar juga muncul beberapa warna yang didominasi warna dasar merah, namun dalam intensitas dan saturasi yang berbeda.

Dalam setiap panel foto, disajikan dari kiri ke kanan detail proses pelapukan yang diperbesar secara optikal dengan cara lebih mendekatkan sudut pemotretan pada objek yang dituju, dalam rangka membandingkan dimensi

proses pelapukan lewat detail yang lebih jelas pada permukaan kayu. Hal tersebut dilakukan secara sadar untuk menangkap imaji yang terkandung dalam proses pelapukan yang terjadi. Sebagaimana imajinasi saya menangkap berbagai bentuk imaji yang terkandung dalam foto. Sebagai tampilan akhir karya, ketiga panel foto sengaja disajikan dalam ketebalan span ram yang berbeda untuk menambah kedalaman dimensi karya, sehingga secara langsung 
hal tersebut memberikan kesan tiga dimensi pada karya.

Dalam proses pemotretan, dipilih perspektif eye level untuk menangkap jelas bentuk objek, sedangkan untuk mempertahankan kedalaman detail yang terkandung, dipilih pemanfaatan cahaya atas yang mempertajam kesan dimensi dan bentuk profil. Pengolahan secara digital dilakukan hanya sebatas contrast dan sharpen, dan tentu saja penentuan ukuran cetak.

Dalam foto pada dapat dilihat sebuah penyadaran akan tiadanya sesuatu yang dapat bertahan abadi di dunia ini. Kayu yang pada masa hidupnya teramat kokoh perlahan menjadi keropos menjalani proses pralina. Terlihat profil wajah tersenyum masingmasing dalam setiap karya, yang makin ke kanan makin diperbesar detailnya sehingga lebih jelas kelihatan profilnya. Dari situ dapat dipetik makna bahwa kayu yang dapat berumur ratusan tahun sangat berbahagia untuk menghadapi masa surut kehidupannya. Seharusnya manusia yang memiliki kesadaran tinggi lebih dapat berbesar hati dalam menghadapi ombang-ambing kehidupan.

Sebuah proses pelapukan berupa karat tersaji dalam karya foto yang berjudul "Antara Hidup dan Mati" ini. Di mana dalam plat besi bekas sebuah pintu kendaraan yang telah tidak terpakai terlihat dominasi cat yang terkelupas dari permukaan plat besi dan kemudian plat yang sudah tidak terlindungi oleh cat perlahan mengalami proses pengembalian unsur ke alam. Karat membuatnya musnah sehingga membentuk lubang cukup ekstrem pada logam. Namun secara visual muncul sebuah imaji estetik dari karat yang meliputi tekstur kasar, kombinasi warna yang kontras antara karat dengan bagian cat yang belum mengelupas. Dengan pemanfaatan cahaya depan yang bersumber dari sinar matahari pagi, saturasi gambar dapat lebih sempurna dan dimensi objek menjadi lebih detail dan eksposur menjadi sempurna.

Dengan pemilihan perspektif eye level bidang objek dapat terekam sempurna baik detail maupun bentuk imajinya secara utuh di keseluruhan bidang. Pengolahan digital hanya dilakukan sebatas contrast untuk memperjelas lagi batasan antara gelap terang gambar dan cropping dalam rangka menampilkan bagian gambar yang inginkan saja dalam tampilan akhir.

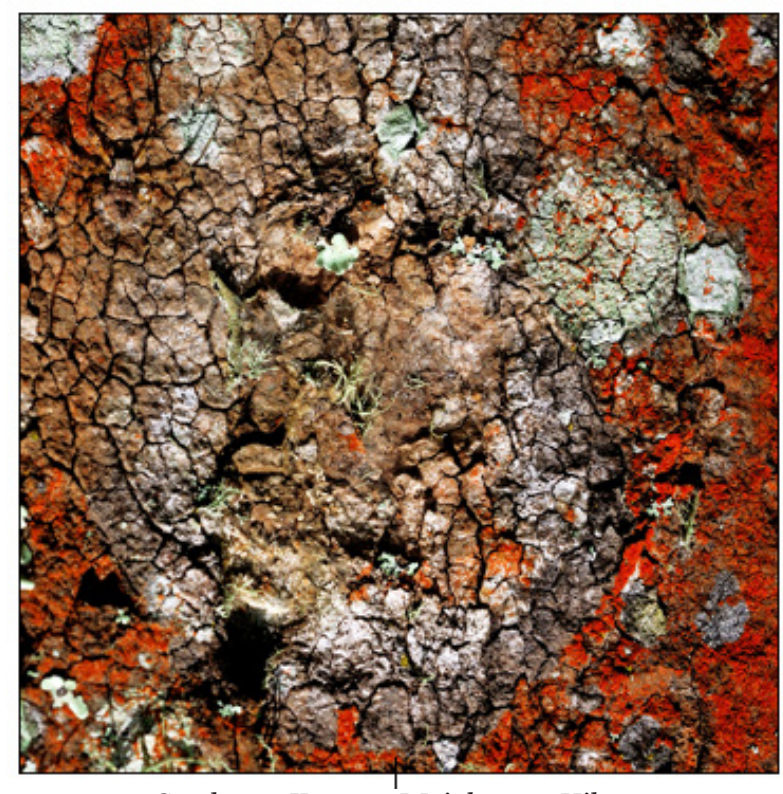

Gambar 9. Karya 3. Wajah yang Hilang

Foto Digital print pada Photo Canvas, $100 \mathrm{~cm} \mathrm{x} 100 \mathrm{~cm}$

Secara visual dapat dilihat dominasi bagian karat dan bagian cat yang cukup berimbang dalam keseluruhan bidang gambar, yang memberi sebuah kesan antara yang hidup dan yang mati. Cat yang belum terkelupas seolah masih bertahan tetap "hidup" dalam kesehariannya, sedangkan bagian karat merupakan bagian yang mengalami pralina. Di sisi lain bentuk profil yang terkandung dalam karat juga seolah memberi bentuk imaji tersendiri dari keseluruhan gambar, yaitu membentuk dua profil wajah dalam satu badan yang tidak dapat dipisahkan. Seperti sebuah daur hidup yaitu hidup dan mati yang tidak pernah dapat terpisahkan. Segala yang pernah hidup atau terciptakan pasti akan mengalami kematian dan kelapukan, cepat atau lambat

Dalam karya "Wajah yang Hilang", ditampilkan sebuah permukaan pohon mati yang sudah mengalami penguraian oleh berbagai makhluk yang mendapatkan kehidupan dari kematian pohon tersebut. Berbagai tekstur yang menarik muncul dalam proses penguraian alam pada permukaan pohon, selain juga berbagai warna seperti dominasi merah dan putih kehijauan yang timbul seolah dilukis oleh alam. Kombinasi gelap terang yang dimunculkan oleh efek dari cahaya atas memberi kesan kedalaman yang lebih detail pada permukaan pohon yang mengalami kehancuran. Dengan perspektif eye level pada saat memotret, kesan keaslian seperti pada tampilan objek aslinya dapat dimunculkan dalam foto. Setelah proses pemotretan, foto di olah dalam Adobe Photoshop CS 3 dengan fitur contrast dalam 


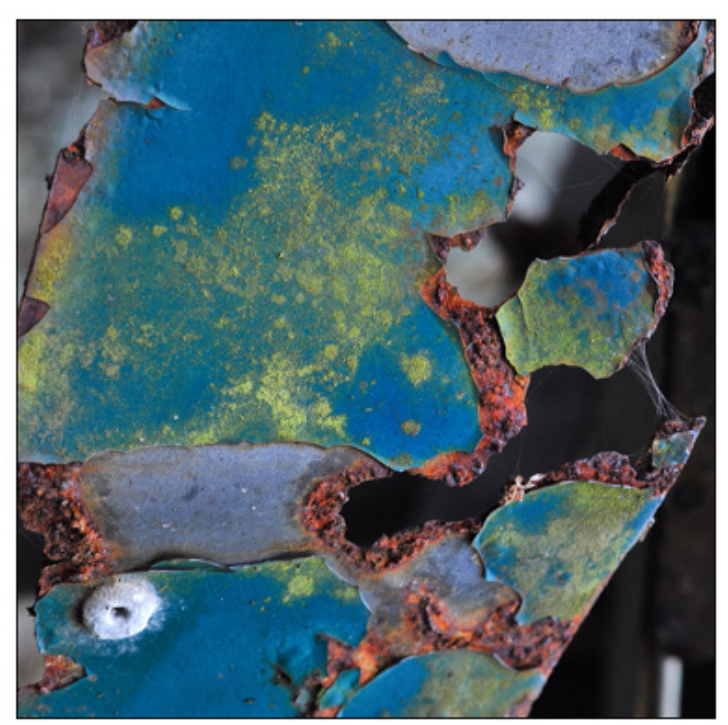

Gambar 10. Karya 4. Akhir Perjumpaan

Foto Digital print pada Photo Canvas, $100 \mathrm{~cm}$ x $80 \mathrm{~cm}$

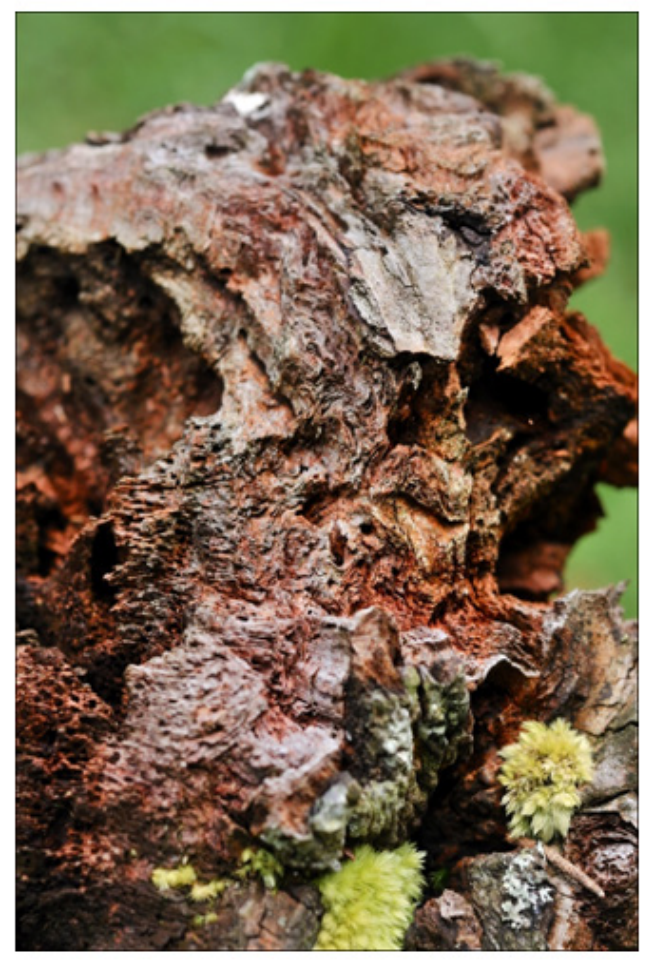

Gambar 11. Karya 5. Infected

Foto Digital print pada Photo Canvas, $80 \mathrm{~cm} \times 100 \mathrm{~cm}$

rangka menambah kekontrasan gambar dan tentu saja menambah perbandingan terang gelap. Selain itu cropping juga dilakukan untuk membuang bagian gambar yang kurang menarik, selain mengubah format gambar menjadi segi empat sama sisi.

Dalam foto ditampilkan sesosok profil wajah yang terlihat samar-samar di antara kombinasi garis, warna dan tekstur yang dominan melengkapi bidang gambar, wajah tersebut seakan-akan segera hilang kenampakannya dari bidang kayu yang menaunginya. Wajah yang hampir hilang tersebut memberi sebuah pesan akan gejala alam tentang berbagai unsur dunia yang selalu berubah, serta selalu mengalami proses pralina. Semua isi dunia diciptakan, tumbuh berkembang, menua dan kemudian hilang dari dunia dalam proses daur hidup yang disebut pralina.

Foto dengan judul "Akhir Perjumpaan" di atas disajikan dengan objek kelapukan pada sepotong plat besi bercat biru kehijauan. Tampak di bidang tersebut karat menggerogoti permukaan plat dan lumut menumbuhi permukaan cat yang masih utuh. Karat juga membuat hilangnya permukaan plat besi hingga tembus dan membentuk profil tertentu.

Perspektif eye level menjadi pilihan dalam menentukan angle dalam pemotretan, karena bidang objek menghadap tepat kearah kamera. Dalam kondisi cahaya tidak langsung menerpa objek, reflektor dijadikan alat bantu untuk memantulkan cahaya matahari kearah objek, sehingga terlihat sifat cahaya yang lebih menyebar dan kesan soft pada foto. Foto diolah secara digital sebatas pada contrast dan level. Selain itu juga dilakukan cropping untuk membentuk bidang gambar menjadi segi empat dan membuang bagian foto yang kurang menarik.

Dalam gambar dapat disaksikan bentuk profil yang diakibatkan oleh karat yang nyaris memutuskan bidang logam yang berkarat, sehingga seolah bagian yang masih utuh tinggal menunggu waktu saja untuk tetap bersama. Dari sana juga dapat dilihat bahwa sisi yang tersaji tidak lama lagi akan terputus oleh proses pelapukan, dan itu dapat saja menjadi akhir perjumpaan bagi bidang logam. Sebelum semuanya dipisahkan oleh penguraian alam.

Sebuah pelapukan pada kayu tua ditampilkan dalam karya berjudul "Lapuk" di atas. Penuaan mengakibatkan seluruh permukaan kayu yang telah mati melapuk, retak dan kemudian mengelupas tidak beraturan. Namun pelapukan tersebut menciptakan beragam garis, warna dan tekstur tidak beraturan yang memberikan sebuah kesan keindahan dalam suasana yang dramatis. Dalam kelapukan yang terjadi, di bagian bawah terlihat dua tumbuhan hidup dengan suburnya.

Dalam pemaknaan dapat dipetik bahwa dari sebuah proses pelapukan, sesuatu yang lapuk dalam proses 
pralina tidaklah musnah sama sekali. Namun dapat menjadi sesuatu yang lebih berguna juga bagi makhluk lainnya. Penguraian dalam kelapukan pada dilakukan oleh pengurai-pengurai alam sampai lenyap berubah wujud menjadi partikel-partikel kecil dalam lapisan humus di tanah yang memberi kesuburan kembali pada ibu pertiwi. Proses pelapukannya tersebut tidaklah merupakan klimaks dari perjalanan sebuah benda, melainkan sebuah siklus alami yang harus dilewati dan dapat memberi dampak positif bagi makhluk lainnya.

Karena cahaya yang cukup minimal di area objek yang ditampilkan, dilakukan pemantulan cahaya dari arah kanan dengan alat bantu berupa reflector berwarna emas yang sekaligus juga memberi kesan kekuningkuningan pada permukaan objek. Pengisian cahaya tersebut juga menambah kedalaman timbulnya dimensi pada objek foto serta memunculkan warnawarna yang terkandung pada objek.

Dengan pengambilan eye level, objek tetap terlihat sama dengan penampilan aslinya. Pemilihan depth of field dipasang pada f/1,8 yang mengakibatkan latar belakang objek menjadi kabur dan terlihat terpisah dengan objek sendiri. Bahkan ruang tajam hanya terlihat di bagian depan objek saja. Setelah pemotretan dilakukan, foto kemudian diolah dengan fitur Level untuk menerangkan bidang gambar lewat Adobe Photoshop CS, Sharpen untuk menajamkan bagian yang diinginkan, serta pengaturan ulang ukuran foto untuk keperluan pencetakan.

\section{DAFTAR RUJUKAN}

Ajidarma, Seno Gumira. (2002), Kisah Mata (Fotografi Diantara Dua Subyek : Perbincangan tentang Ada). Yogyakarta : Galang Press.

Bagus, Lorens. (2002), Kamus Filsafat. Jakarta : PT. Gramedia Pustaka Utama.

Boas, Keith A.(Ed). (1981), More Joy of Photography. Eastman Kodak Company.

Daryanto. (2001), Teknik Fotografi. Semarang : Aneka Ilmu.

Djelantik, (2004), A. A. M. Estetika : Sebuah Pengantar. Bandung : Masyarakat Seni Pertunjukan Indonesia.
Freeman, John. (2005), Photography : The New Complete Guide to Taking Photographs. Singapore : Page One Publishing Private Limited.

Gie, The Liang. (2004), Pengantar Filsafat Ilmu. Yogyakarta : Liberty.

Kim, John. (2004), 40 Digital Photography Technique. Jakarta : Elex Media Komputindo.

Marah, Risman (Editor) (2008), Soedjai Kartasasmita di Belantara Fotografi Indonesia. BP ISI Yogyakarta.

Mortensen, William. (1938) Print Finishing. San Fransisco : The Mercury Press.

Nardi, Leo. (1996), Diktat Fotografi. Bandung.

Nugroho, R. Amien. (2006), Kamus Fotografi. Yogyakarta : Penerbit Andi.

Snap Photo Techniques : Vital Skills Guide.(2007), Jakarta : PT. Penerbitan Sarana Bobo Gramedia Majalah.

Soedjono, Soeprapto. (2006), Pot-Pouri Fotografi. Jakarta : Penerbit Universitas Trisakti.

Soelarko, R.M. (1978), Komposisi Fotografi. Bandung : PT. Indira.

Sumardjo, Jakob. (200o), Filsafat Seni. Bandung : Penerbit ITB.

Zahar, Iwan. (2003), Catatan Fotografer: Kiat Jitu Menembus New York. Jakarta : Penerbit Kreativ Media

Jurnal :

Anom, A. S., \& Revias Purwa Kusuma, M. (2019). Pengungkapan Estetika Fotografi "Instagramable” Di Era Pariwisata Destinasi Digital. Mudra Jurnal Seni Budaya, 34(3), 319-324. https://doi.org/10.31091/ mudra.v34i3.787

Saryana, I. M., Raharjo, A., \& Octaviano, A. L. (2018). Desain Ilustrasi Foto Pada Baju Kaos Dengan Media Fotografi Digital Pendukung Pariwisata Budaya Di Pura Tanah Lot Dan Taman Ayun. Mudra Jurnal Seni Budaya, 33(1), 154-16o. https://doi.org/10.31091/ mudra.v33i1.313 
Wirakesuma, I. N. (2017). Ekpresi Wajah Reinterpretasi Visual Di Balik Karakter Dewata Nawa Sanga. Mudra Jurnal Seni Budaya, 32(1). https://doi. org/10.31091/mudra.v32i1.90 